\title{
SPECTACOLELE REGIZORULUI CRIN TEODORESCU
}

\author{
Raluca Blaga
}

DOI 10.46522/CT.2021.02.04

\begin{abstract}
:
The Performances of the Stage Director Crin Teodorescu
\end{abstract}

This present article follows in a chronological manner Crin Teodorescu's performances. An important figure of Romanian theatre in the 1960s, the stage director proved to be a theatrical voice that was brave enough to ask important questions: why theatre? why do we make theatre? Every performance that carries his signature seems to rethink the perspective upon which we regard theatre. A stage director not too often mentioned and almost forgotten, Crin Teodorescu represents for the author of this article an important theatrical voice that must be listened today.

\section{Keywords:}

Crin Teodorescu; stage-directing; history of Romanian theatre; 1960s Romanian theatre; archives.

$\mathrm{F}$ orța de a le refuza lumina tiparului unor rânduri scrise, nenecesare în ansamblul întregului cu privire la un subiect anume, reprezintă punctul în care esențializarea și scopul demersului întreprins își reclamă autoritatea.

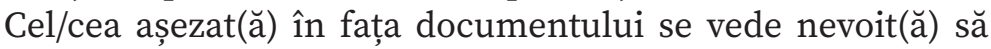
opereze decizii. M-am aflat în fața unei astfel de hotărâri în toamna acestui an, atunci când am predat, pentru portalul Dicționarul Multimedia al Teatrului Românesc, biografia artistică a regizorului Crin Teodorescu ${ }^{1}$. Lunile dedicate

1. V., în acest sens, Raluca Blaga, Crin Teodorescu, Dicționarul 
documentării au dat naștere unui material amplu, stufos, complex. Nu toate elementele care au fost pregătite pentru a intra în componența articolului îi erau și necesare. Consider însă că aceste elemente adunate atunci trebuie să vadă lumina tiparului într-un alt context, sub o formă distinctă. Aici, intră în joc conținutul articolului de față: prezentarea cronologică a traseului spectacologic asupra căruia s-au așezat pașii regizorali ai lui Crin Teodorescu. Cred că vocea artistică și teoretică a celui care a fost Crin Teodorescu merită să fie ascultată încă o dată, întrucât se poate dovedi fertilă pentru un câmp teatral încă neexplorat la adevăratele sale dimensiuni. Articolul de față propune atât perspectiva regizorului, ivită din propriile articole sau regăsită în paginile caietelor-program, cât și perspectiva criticii contemporane cu privire la aceste demersuri teatrale. Totodată, pentru a-și împlini misiunea, autoarea articolului Spectacolele regizorului Crin Teodorescu vă îndeamnă, pentru a beneficia de o perspectivă completă, să parcurgeți și materialul disponibil între „paginile“ Dicționarului Multimedia al Teatrului Românesc.

\section{Primele spectacole, prim-regizor, directoratul gălățean}

Numărul 12/1967 al revistei Teatrul conține un material amplu coordonat de Florin Tornea intitulat 21 de animatori și creatori de spectacole despre etape și momente memorabile din acești 20 de ani. Grupajul este dedicat istoriei recente a teatrului românesc. În articolul său intitulat Viitorul aparține unor colective mici, Crin Teodorescu își prezintă, după o „triere severă“2, o listă care conține cinci dintre spectacolele sale semnificative, puse în scenă până la acea dată. Din lista menționată fac parte și două dintre primele sale puneri în scenă la teatrele din Brăila și Galați (este vorba despre spectacolele Viața nouă și Preludiu). Comentariul semnat de Crin Teodorescu se dovedește important în ceea ce privește începutul activității sale de regizor,

Multimedia al Teatrului Românesc, octombrie 2021, https://www. doi.org/10.47383/DMTR.02.03.

2. Crin Teodorescu, „Viitorul aparține unor colective mici“, în Teatrul, anul XII, nr. 12, decembrie 1967, p. 38. 
dar, mai ales, importantă este și perspectiva sa artistică, fie ca prim-regizor, fie ca director al teatrului gălățean. Într-o perioadă în care încă se simțeau urmele războiului, iar în paginile revistelor de specialitate urmau discuții ample despre rostul și locul regiei de teatru, Crin Teodorescu reușește ca, la doar un an de la deschiderea Teatrului de Stat Galați, să obțină cu spectacolul Preludiu de Ana Novac Premiul I la Decada dramaturgiei originale. Până la acel moment, Teodorescu pusese în scenă doar patru spectacole, toate pe scena Teatrului de Stat Brăila: Viața nouă de Anton Semenovici Makarenko (1954), Curentul subteran de Albert Maltz (1954), Spectacol Cehov (1954), Micii burghezi, de Maxim Gorki (1955). În punerile în scenă de la Brăila, realizate împreună cu o echipă formată din tineri, Crin Teodorescu menționează unul dintre principiile ordonatoare pe care le-a urmat: „o încorporare a emoției în mișcare“ ${ }^{\text {. }}$. Impresionat de o povestire despre spectacolele lui Vahtangov, regizorul își dorea să construiască pe scenă „un dinamism organic, un joc exploziv și uneori chiar acrobatic"4. Toate aceste gânduri artistice vor fi împlinite și desăvârșite în spectacolele realizate ulterior la Galați.

Încă de la înființarea Teatrului de Stat Galați ${ }^{5}$, Crin Teodorescu devine prim-regizor al instituției, iar, în perioada mai 1956-februarie 1957, ocupă funcția de director al teatrului. Primul spectacol care deschide, în fapt, recent înființatul teatru are la bază piesa Anei Novac, Preludiu. Conform informațiilor primite de la secretariatul literar al teatrului, premiera a avut loc în ziua de 14 aprilie 1956 și s-a desfășurat în sala Orchestrei Simfonice de Stat (devenită, mai târziu, Sala Teatrului Muzical Nae Leonard). Din distribuția spectacolului, făceau parte și Matei Alexandru, Ștefan Iordănescu, Ștefan Bănică, Mihai Pălădescu, Dana Comnea. La doar o lună de la data

3. Ibidem, p. 39.

4. Ibidem.

5. Teatrul de Stat Galați se înființează în data de 16 septembrie 1955. Anterior, locuitorii orașului avuseseră parte de spectacole puse în scenă la Teatrul de Stat Brăila-Galați, înființat în 24 aprilie 1949. V. Mihai Florea, „Teatrul românesc contemporan și societatea socialistă“, în: Teatrul românesc contemporan 194-1974, coordonatorii ediției: Simion Alterescu, Ion Zamfirescu, București, Meridiane, 1975, pp. 32-33. 
premierei, spectacolul va participa la Decada dramaturgiei originale organizată de Ministerul Culturii, în perioada 20-30 mai 1956, în București ${ }^{6}$. Concurând în fața juriului cu alte douăzeci și două de teatre ${ }^{7}$, spectacolul regizat de Crin Teodorescu devine „surpriza decadei“" și va primi mai multe aprecieri din partea juriului: Premiul I acordat Colectivului Teatrului de Stat Galați pentru spectacolul Preludiu de Ana Novac, Premiul I individual pentru regie îl obține și Crin Teodorescu pentru acest spectacol, iar actorul Matei Alexandru obține o Mențiune pentru rolul Adam. Într-o convorbire cu artistul poporului Costache Antoniu din 8 iunie 1956, apărută în revista Scânteia, acesta, membru al juriului Decadei, menționează drept remarcabil faptul că un teatru recent înființat reușește o astfel de performanță: „la Galați, Crin Teodorescu a realizat un spectacol unitar, închegat, a știut să pună în valoare forțele întregii echipe“" . La rândul său, George Rafael, în articolul dedicat spectacolului, va aprecia maturitatea regizorală de care a dat dovadă Crin Teodorescu, precum și nivelul de exigență pe care 11 impune acest demers artistic. Subliniind dificultatea de a pune în scenă textul Anei Novac ${ }^{10}$, George Rafael remarcă, în ceea ce privește regia semnată de Crin Teodorescu, „o gîndire care scotocește în adâncime caracterele eroilor, o migală de ceasornicar pasionat de amănunte, fără a pierde totuși din mînă sensul principal al situațiilor scenice, nota lor dominantă, căutînd în permanență adevărul sentimentelor, simplitatea și o delicată tălmăcire a poeziei textului““11.

6. V. comunicatul Agerpres din Scânteia, iunie 1956.

7. V. Mira Iosif, „În zilele Decadei“, în Teatrul, anul I, nr. 3, august 1956, p. 28. 8. Ibidem.

9. „Pasiune și însuflețire în arta teatrală“, convorbire cu artistul poporului Costache Antoniu despre decada dramaturgiei originale, în: Scânteia, anul XXV, nr. 3616, vineri 8 iunie 1956.

10. Autoarea nu devenise încă un caz problematic. V., în acest sens, capitolul „«Cazul» Novac“, în: Miruna Runcan, Teatru în diorame. Discursul criticii teatrale în comunism. Fluctuantul dezgheț 1956-1964, București, Tracus Arte, 2019.

11. George Rafael, „Un preludiu promițător“, în Teatrul, anul I, nr. 3, august 1956, p. 66. 
Timp de câțiva ani, teatrul din Galați devine un spațiu propice căutărilor și cercetării teatrale. Crin Teodorescu menționează unul dintre principiile pe care le-a urmat atât ca prim-regizor, cât și ca director: „de lucru cu și în echipă. Am «fondat» atunci un teatru - gândit într-un anume fel - axat pe principiul echipei“12. Trupei i se va alătura, la dorința precisă a lui Crin Teodorescu, și tânărul Valeriu Moisescu, cel care, student fiind, se anunța drept un tip de regizor care va manifesta ,periculoase tendințe formaliste “13 [sic!]. Valeriu Moisescu menționează, în scrierile sale, atmosfera specială care se crease în acest teatru de provincie: „la Galați, nu fusesem repartizați la un teatru care ființa, ci la un teatru care lua ființă - ceea ce e cu totul altceva. Teatrul din Galați s-a constituit cu noi și prin noi" ${ }^{114}$. În timpul direcției sale artistice, Crin Teodorescu a conturat cadrul pentru apariția unui „climat cu adevărat creator“15. Nu este întâmplător faptul că i-a oferit lui Valeriu Moisescu direcția artistică a spectacolului care urma să deschidă noua sală a teatrului - aici, Moisescu va pune în scenă pentru prima dată textul lui Caragiale, D'ale carnavalului. Un al doilea spectacol care poartă semnătura regizorală a lui Crin Teodorescu este Don Gil de Ciorap verde de Tirso de Molina. Spectacolul, a cărui premieră a avut loc în 22 iunie 1957, o avea în distribuție și pe Gina Patrichi care, deși fusese exmatriculată de la Institut ${ }^{16}$, este angajată la Teatrul de Stat Galați. Din articolul semnat de Ovidiu Drîmba, observăm, în cazul lui Crin Teodorescu, continuarea proiectului său artistic, ale cărui linii directoare începuseră încă de la spectacolele realizate la Brăila: regia „preocupată mai mult de plastică și de mișcare decît de idei“17. În aceeași perioadă, la Teatrul de Stat din Galați, va realiza și Radu Penciulescu spectacolul Hanul de la

12. Crin Teodorescu, Viitorul aparține unor colective mici, art. cit., p. 39.

13. Valeriu Moisescu, Persistența memoriei, art. cit., p. 12.

14. Ibidem, p. 14.

15. Ibidem, p. 15.

16. V. capitolul „Actriță la Galați“, în: Mircea Morariu, Carte cu Gina Patrichi, Fundația Culturală „Camil Petrescu“, Revista „Teatrul azi“ (supliment), București, 2009.

17. Ovidiu Drîmba, „Mai multă plastică decât idei“, în Teatrul, anul II, nr. 9, septembrie 1957, p. 74. 
răscruce. Însă, așa cum menționează Crin Teodorescu, ,această echipă și spiritul de lucru special care a dominat acolo s-a menținut doi ani. Din păcate, condițiile particulare locale n-au fost prielnice dezvoltării teatrului în această direcție. Au intervenit și tentațiile capitalei, care au absorbit o mare parte din membrii colectivului, ceea ce a dus la o inevitabilă destrămare“18.

\section{Spectacolele ieșene}

Pe scena Teatrului Național „Vasile Alecsandri“ din Iași, Crin Teodorescu va semna regia unui număr de nouă spectacole și unul care ia forma unui laborator/atelier (Festival de tragedie antică). În cei cinci ani de lucru cu trupa teatrului ieșean, pare că regizorul și-a continuat câteva dintre principiile artistice cu care plecase la drum și la teatrul din Brăila, dar mai ales la cel din Galați. Din acest punct de vedere, ilustrativ se dovedește paragraful care deschide capitolul dedicat regizorului de Ștefan Oprea în cartea sa, Martor al Thaliei: „venirea la Iași a regizorului Crin Teodorescu, în stagiunea 1963-1964, avea să însemne începutul unei perioade de revigorare a artei spectacolului, artă ce părea obosită, cantonată în rutină și tradiție unilateral înțeleasă“'19.

Primul din această serie de spectacole pornește de la o piesă publicată în urmă cu doar câțiva ani de Sergiu Fărcășan, Steaua polară. Așa cum mărturisește Crin Teodorescu în caietul-program al spectacolului, scopul întregii construcții regizorale și actoricești fusese acela de a pune în valoare poezia cotidianului: „într-o piesă bună totul seamănă și parcă nu seamănă cu viața, pare că totul e ca în viață și, totuși, văzînd-o, recunoști unele aspecte din viață de care nu-ți dăduseși seama destul de clar până atunci“ ${ }^{\text {20 }}$. În cronica pe care Florian Potra o semnează în numărul din iunie 1964 al revistei Teatrul descoperim reușita

18. Crin Teodorescu, Viitorul aparține unor colective mici, art. cit., pp. 39-40. 19. Ștefan Oprea, „Patru regizori în «perioada ieșeană». Crin Teodorescu sau calmul aparent al apei adânci“, în: Ștefan Oprea, Martor al Thaliei, Iași, Editura Junimea, 1979, p. 46.

20. Crin Teodorescu, „Opinii regizorale“, în caietul-program al spectacolului Steaua polară, de Sergiu Fărcășan, Teatrul Național „Vasile Alecsandri" Iași. 
spectacolului, dar și faptul că regizorul a ridicat primul act al spectacolului peste cel al textului dramatic. Cel de-al doilea proiect artistic pentru scena ieșeană ia forma unui laborator/atelier de creație actoricească. Având caracterul de experiment, menit a se desfășura în condiții de studio, dar mai ales având scopul de a deveni „factor de informare pentru public și de exercițiu scenic pentru actori“'21, Festivalul de tragedie antică va intra însă, datorită succesului, în repertoriul curent al teatrului.

A cincea premieră a stagiunii ieșene a avut loc marți, 31 martie 1964. Crin Teodorescu a ales Noaptea regilor ${ }^{22}$ și dramaturgia lui William Shakespeare. Se împlineau, la acea dată, 400 de ani de la nașterea dramaturgului englez și, în țară, rețin atenția criticilor spectacolele având la bază piesele sale. În cronica dedicată și Nopții regilor de la Iași, Ileana Popovici apreciază, în mod deosebit, două dintre montările Shakespeare ale acelei stagiuni, ambele având la bază aceeași piesă shakespeariană: spectacolul ieșean, în regia lui Crin Teodorescu, și pe cel regizat de Vlad Mugur, la Bacău. Din aprecierile pe care Ileana Popovici le face cu privire la Noaptea regilor, descoperim sensul imprimat de regizor direcției scenice: accentul înspre comic, carnavalesc, înspre „caracteristicile de stil ale spectacolului popular“23. Atenția regizorului se concentrase, pornind de la analiza atentă și precisă a textului (,caracterizată prin cultură și profunzime“ “24 - cum a descris-o autoarea cronicii), tocmai înspre punerea în valoare a calităților și aptitudinilor actorilor din distribuție. Astfel, se explică minuțiozitatea aleasă de Crin Teodorescu în descrierea pe care le-o face personajelor piesei în paginile caietului-program al spectacolului.

Următoarea stagiune a Teatrului Național „Vasile Alecsandri“ din Iași se deschide cu premiera spectacolului Bălcescu.

21. Florian Potra, „Două spectacole de tragedie ateniană“, în Teatrul, anul IX, nr. 5, mai 1964, p. 97.

22. Este vorba de versiunea tradusă de Florian Nicolau a piesei lui William Shakespeare, A douăsprezecea noapte.

23. Ileana Popovici, „Spectacole Shakespeare“, în Teatrul, anul IX, nr. 9, septembrie 1964, p. 89.

24. Ibidem, p. 91. 
Dincolo de aspectele ideologice și revoluționare pe care $\mathrm{i}$ le pusese la dispoziție piesa lui Camil Petrescu, Crin Teodorescu detectează, în aerul epocii, o vibrație: „atracția, fascinația chiar, pe care tinerii generației de azi o resimt pentru literatura lui Camil Petrescu, în al cărui aliaj sufletesc - de «luciditate și febră», de incandescență intelectuală, de vehement refuz al compromisului și mediocrității - ei se regăsesc“ ${ }^{25}$. Spectacolul său va răspunde în mod artistic și acestei vibrații. În analiza dedicată spectacolului ieșean, Florin Nicolau remarcă maniera de o extraordinară plasticitate a prezenței revoluției pe scenă - „prin forța ideilor lui Bălcescu, prin nestăvilita lui pasiune revoluționară“ ${ }^{26}$, precum și pe cea a dispozitivului scenic realizat de Margareta Ene, care a contribuit la stilul cinematografic al punerii în scenă. Mira Iosif, în materialul dedicat spectacolului din Scânteia, subliniază și o altă premieră a spectacolului: regizorul a ales să pună în scenă și ultimele două tablouri ale piesei, nereprezentate până atunci. Parte a aceleiași stagiuni a fost și spectacolul Vară și fum de Tennessee Williams. Alegerea dramaturgului american și a acestei piese este privită de Crin Teodorescu ca o punte de legătură între gustul actual al publicului ieșean și propriile afinități teatrale: pentru a-și pregăti publicul pentru întâlnirea cu dramaturgia lui Brecht, Ionescu, Dürrenmatt, Frisch, Osborne, Sartre sau cea a lui Shaw (tocmai autorii de care el se simte mai apropiat), regizorul le propune spectatorilor abordarea din perspectivă umanistă, nu din cea patologică sau ideologică, a lumii și personajelor din Vară și fum $^{27}$. Continuarea demersului regizoral început de Crin Teodorescu la Iași a fost dorită și de conducerea Naționalului ieșean, întrucât, așa cum ne mărturisește Dana Crivăț în

25. Crin Teodorescu, „Cuvântul regizorului“, extras din caietul-program al spectacolului Bălcescu, Teatrul Național „Vasile Alecsandri“ Iași, stagiunea 1964-1965.

26. Florin Nicolau, „«Bălcescu» de Camil Petrescu la Teatrul Național «Vasile Alecsandri»", în Teatrul, anul IX, nr. 12, decembrie 1964, p. 58. 27. V. „De vorbă cu Crin Teodorescu regizorul spectacolului“, material disponibil în caietul-program al spectacolului Vară și fum, Teatrul Național „Vasile Alecsandri“ Iași, stagiunea 1964-1965. 
articolul din Teatrul dedicat stagiunii ieșene ${ }^{28}$, începând cu acel an, Crin Teodorescu a fost angajat ca regizor permanent.

Între spectacolele sale pe care le consideră seminficative, Crin Teodorescu amintește în articolul „Viitorul aparține unor colective mici“ și Din jale se-ntrupează Electra. Seria cu reprezentațiile scenice ale piesei lui Eugene O’Neill începe în luna iunie a anului 1966. În amplul material din revista Teatrul dedicat acestei puneri în scenă, Florin Tornea include și un scurt interviu cu regizorul spectacolului. Crin Teodorescu conferă prospețime și acestei lecturi scenice a textului lui O’Neill. Pornind de la cuvintele autorului american, care își dorea transpunerea sub formă dramaturgică contemporană a tragicului, trecând prin lectura unor capitole din Fenomenologia spiritului lui Hegel, regizorul spectacolului ieșean și-a propus să conducă firele artistice înspre revelarea următorului sens: „drumul înțelegerii de sine: iată ce mi s-a părut a fi linia de bază, subterană, a operei lui O’Neill, linia pe care am crezut că trebuie s-o urmăresc și s-o scot în evidență în spectacol“29. Aceste gânduri au plecat și către Paul și Maria Bortnovschi, cei care au construit spațiul scenic. Rezultatul este apreciat în termeni laudativi de autorul cronicii: „Linia magistrală a viziunii regizorale, ca să zic așa, apărea evidentă“30 . Apecieri similare vin și din partea lui Radu Popescu. În materialul din România liberă, acesta preferă varianta de spectacol de la Iași, celei din București ${ }^{31}$. În articolul ei din Contemporanul, Mariana Bărbuță găsește punerea în scenă semnată de Crin Teodorescu drept ,convingătoare artisticește“332.

28. V. Dana Crivăț, „Prin teatrele din țară: Iași“, în Teatrul, anul X, nr. 6, iunie 1965.

29. Florin Tornea, „Crin Teodorescu și căile tragicului modern: «Din jale se întrupează Electra» de Eugene O'Neill la Teatrul Național «Vasile Alecsandri» din Iași“, în Teatrul, anul XI, nr. 11, noiembrie 1966, p. 44. 30. Ibidem.

31. Autorul cronicii se referă la spectacolul Naționalului bucureștean în regia lui Alexandru Finți, care avusese premiera în luna februarie a aceluiași an.

32. Apud Crin Teodorescu, Maeștri ai teatrului românesc în a doua jumătate a secolului XX, coordonator Valeriu Moisescu, UNATC, 2001, p. 280. 
În stagiunea 1966/1967, Crin Teodorescu se oprește, din nou, asupra unei piese românești. Ales ca o celebrare a 150 de ani de la apariția teatrului cult românesc, spectacolul având la bază piesa lui Vasile Alecsandri, Despot Vodă, se înscrie în galeria sa de căutări artistice. În interviul publicat în Martor al Thaliei, regizorul menționează faptul că punctul său de atenție s-a îndreptat, cu acest spectacol, înspre revitalizarea textului lui Alecsandri, urmărind atent „un teatru de relații, de portretizare, de adevăr psihologic, social, istoric“33. În această direcție, a condus și colaborarea cu scenograful Paul Bortnovschi, înspre o expresie scenică a ,concretului artei moldovenești“34. Citind astăzi cronicile dedicate spectacolului, fie că este vorba de observațiile lui Ștefan Oprea sau de cele ale lui C. Paraschivescu, descoperim că intențiile teoretice ale lui Crin Teodorescu s-au și materializat scenic. Cei doi cronicari menționează, în observațiile lor, un minus în ceea ce-l privește pe interpretul personajului central, Despot; Crin Teodorescu s-ar fi îndepărtat, prin propria lectură scenică, de direcția general acceptată a piesei lui Alecsandri, și anume de acea direcție conform căreia Despot Vodă este un text dramatic de factură romantică și are în centrul său un erou excepțional cu trăsături pe măsura curentului artistic din care face parte. $\mathrm{Cu}$ toate acestea [sic!], susține C. Paraschivescu, spectacolul ne-a propus „o reevaluare în adâncime, așadar, o reconsiderare a fondului material și uman al faptelor înscrise în istorie.“35

Aniversarea a o sută de ani de la nașterea lui Luigi Pirandello a stat la baza alegerii piesei Îmbrăcați pe cei goi ca parte a repertoriului stagiunii 1967-1968. Într-un scurt interviu publicat de Ștefan Oprea, Crin Teodorescu menționează faptul că „în România - și în special în Iași - există o veche tradiție a pirandellismului “36. El amintește spectacolele memorabile

33. Ștefan Oprea, „Patru regizori în «perioada ieșeană». Crin Teodorescu sau calmul aparent al apei adânci“, în: Ștefan Oprea, Martor al Thaliei, Iași, Editura Junimea, 1979, p. 48.

34. Ibidem.

35. C. Paraschivescu, „Teatrul National din lași: «Despot Vodă» de Vasile Alecsandri“, în Teatrul, anul XII, nr. 2, februarie 1967, p. 80.

36. Ștefan Oprea, „Patru regizori în «perioada ieșeană». Crin 
realizate de Ion Sava, Tudor Călin, Aurel Ion Maican și își plasează demersul regizoral în linia interesului contemporan suscitat de dramaturgia autorului italian. Ștefan Oprea consideră punerea sa în scenă drept una reușită: ,,spectacolul are o ținută artistică ridicată, impune prin acuratețea imaginii scenice și prin dinamică interioară. Cunoscând foarte bine teoriile lui Pirandello și exegezele asupra operei pirandelliene, Crin Teodorescu a urmărit acordarea concepției sale asupra textului cu aceste teorii; de aici ținuta intelectuală a spectacolului, dar și senzația că, pe alocuri, s-a tradus pe scenă teoria, nu textul, că teoriile s-au suprapus peste partitura dramatică. Cauza undelor glaciale care străbat, din când în când, spectacolul, probabil că aici trebuie căutată“37. Dar dacă ar fi să ascultăm vocea criticului N. Barbu, așa cum se aude ea din paginile cronicii sale din România liberă, am vedea că ne propune să observăm în cazul acestui spectacol tocmai lipsa de atenție acordată de regizor implicării intelectuale a spectatorului: ,dimensiunea pirandelliană ar fi fost servită mai consecvent, în spectacol, prin aflarea unei a treia tonalități, într-un plan mai priicios dezbaterii etice. [...] O estompare a liniilor prea insistent trasate, o concentrare a interpretării, o seninătate care devine elocventă pentru sensul creator (paradoxal!) pozitiv, am spune, dar termenul e prea uzat - al festului Ersiliei, bunăoară, în locul crispării și al suferinței viu redate, poate ar permite participarea intelectuală a spectatorului. Uneori, din buna intenție de a-i oferi prea mult, se poate să-i dăm prea puțin““38. $\mathrm{O}$ a treia sursă aduce un plus de lămuriri. Materialul Danei Crivăț poate fi privit, mai degrabă, ca o mea culpa cu privire la prejudecățile pe care criticii, în special, și le formează în legătură cu posibilitățile de punere în scenă a unui text dramatic. Autoarea face o trecere în revistă a numeroaselor materiale critice despre dramaturgia lui Pirandello pe care le-a parcurs anterior vizionării

Teodorescu sau calmul aparent al apei adânci“, art. cit., p. 54.

37. Ibidem, pp. 59-60.

38. Apud Crin Teodorescu, Maeștri ai teatrului românesc în a doua jumătate a secolului XX, ed. cit., pp. 284-285. 
spectacolului de la Iași. Afirmația care urmează edifică direcția cronicii sale: „Mă întrebam chiar dacă mai are vreun rost să aștept să se ridice cortina: spectacolul mi-era atît de limpede!“39. Însă, odată ridicată cortina, Dana Crivăț constată că versiunea scenică propusă de Crin Teodorescu nu coincide cu teoriile critice consumate anterior. În plus, replicile dramaturgului italian au tonuri diferite, iar sensul lor capătă valențe noi. Ajunsă acasă, autoarea verifică textul lui Pirandello, fiind convinsă de faptul că regizorul a operat modificări, a adaptat textul dramatic. Însă textul dramatic coincidea cu cel scenic. Așadar, Dana Crivăț nu poate decât să concluzioneze: „Și-atunci, în loc să criticăm spectacolul și regizorul de a nu fi respectat prejudecățile noastre, mi se pare mai cuvenit să le mulțumim pentru seara în care am simțit din nou nevoia să-l privim pe Pirandello cu ochi proaspeți “40.

La doar o lună de la premiera spectacolului Îmbrăcați pe cei goi, are loc ultimul spectacol a cărui regie o va semna Crin Teodorescu pe scena Teatrului Național „Vasile Alecsandri“ din Iași. Este vorba despre spectacolul Opinia publică de Aurel Baranga. $\mathrm{Cu}$ acest spectacol, se va închide seria punerilor sale în scenă la Iași. Misiunea și direcția artistică pe care regizorul a încercat să le imprime acestei trupe de teatru dezvăluie, în fapt, o latură importantă a personalității sale regizorale: „O dorință similară de animare a unui colectiv am simțito când am venit la Iași. Sosisem într-un moment extrem de dificil pentru teatru - lipseau regizori, colectivul era descompletat și dezorientat, moment contrastant cu o perioadă anterioară valoroasă [...]. La Iași - teatru unde predomina spiritul unei generații vârstnice - mi s-a părut important să mă sprijin pe elementele în plină afirmare, pe resursele tineretului. Repertoriul ales a fost gândit pe o mare gamă de extensie și construit pe principiul unor spectacole-școală pentru actori. De aceea am programat scriitori și genuri diverse, de la spectacole de selecțiuni din tragedia antică la comedia shakespeariană, de la drama istorică modernă a lui

39. Dana Crivăț, „Prin teatrele din țară: Iași - «Îmbrăcați pe cei goi» de Luigi Pirandello, «Întâlnire la Copenhaga» de Yves Jamiaque“, în Teatrul, anul XIII, nr. 4, aprilie 1968, p. 61.

40. Ibidem, p. 62. 
Camil Petrescu, Bălcescu, la dramaturgia americană reprezentată de O'Neill și Tennessee Williams. Rezultatele au fost numaidecît vizibile: pentru prima oară, colectivul ieșean a fost distins cu premiul întîi pentru cea mai originală realizare a anului (Steaua polară de Sergiu Fărcășan) ${ }^{\text {“411. }}$.

\section{Două opriri la Teatrul Național „Lucian Blaga“ din Cluj-Napoca}

Procesul Horia, piesa istorică a lui Alexandru Voitin, intrase în repetiții în anul 1967, în două teatre în același timp: la Teatrul „Lucia Sturza Bulandra“, în regia lui Liviu Ciulei, și la Teatrul Național „Lucian Blaga“ din Cluj-Napoca, în regia lui Crin Teodorescu. Numărul din luna martie al revistei Teatrul conține în paginile sale referințe cu privire la aceste două versiuni ale aceluiași text dramatic. Crin Teodorescu consideră că sensiblitatea contemporană nu se mai lasă impresionată de reconstituirea ca într-un muzeu a unui moment din trecut sau de apelul la recuzite și elemente fastuoase. Drept urmare, regizorul le propune dramaturgilor care își iau drept subiecte momente istorice să aibă în vedere să înlocuiască „trâmbițarea patetică a vorbelor mari cu forța probantă a documentului, cu analiza lucidă a faptelor, cu demontarea mașinăriei istoriei “42. O astfel de direcție a găsit în dramaturgia lui Alexandru Voitin. Spectacolul care a rezultat pare să fi împlinit, așa cum remarcă Ștefan Oprea, perspectivele teoretice ale regizorului: „Sesizând că procesul acesta este neobișnuit ca factură, regizorul Crin Teodorescu a ocolit aspectele lui pur juridice, punînd accentele pe dezbaterea politică, cea care alcătuiește de fapt esența procesului. Cauzele răscoalei apar astfel într-o lumină precisă, ca și complexitatea evenimentelor istorice care au determinat înfrângerea ei ${ }^{\text {“43 }}$. Comparând trei versiuni ale aceluiași text (cea de la Bulandra a lui Liviu

41. Crin Teodorescu, Viitorul aparține unor colective mici, art. cit., p. 40. 42. Ana Maria Narti, „Procesul Horia văzut de regizorii Liviu Ciulei și Crin Teodorescu“, în Teatrul, anul XII, nr. 3, martie 1967, p. 16.

43. Ștefan Oprea, „Patru regizori în «perioada ieșeană». Crin Teodorescu sau calmul aparent al apei adânci“, art. cit., p. 65. 
Ciulei, varianta craioveană semnată de Miron Niculescu și cea a lui Crin Teodorescu), Traian Șelmaru remarcă, în cazul spectacolului de la Teatrul Naţional „Lucian Blaga“ din Cluj-Napoca, o versiune mult mai personal gândită decât cea bucureșteană. Autorul cronicii subliniază faptul că „textul a fost tratat în perspectiva unui realism poetic, generator de valori inedite. Renunțind la prolog, Crin Teodorescu a situat drama la intersecția dintre realitate și legendă“44. $\mathrm{O}$ astfel de apreciere se dovedește exponențială pentru tipul de lectură scenică a unui text pentru care, adeseori, a optat Crin Teodorescu.

Cel de-al doilea spectacol al scenei clujene care poartă semnătura lui Crin Teodorescu a avut premiera simultan cu versiunea regizată de Sorana Coroamă a piesei lui Eugene O'Neill, Lungul drum al zilei către noapte. În varianta de la Cluj-Napoca, așa cum remarcă Ileana Popovici în cronica ei din revista Teatrul, Crin Teodorescu a mizat pe redarea scenică a contrariilor: „pe înfruntarea dintre nevoia de seninătate, ordine și echilibru, fireasca tendință de căutare a securității în normal, pe de o parte, și duhul stârnit al autodistrugerii, lipsit de orice scrupul în opera sa de disoluție, pe de altă parte“45. Specific modalităților sale de punere în scenă, regizorul alege și de această dată să trateze piesa lui O’Neill din perspectivă umanistă. Așadar, scena devine spațiul de observație și de disecție a încercării personajelor de a raționaliza iraționalul, spectatorii asistând, în fapt, la plonjarea în vid a existențelor supuse analizei. La toate aceste perspective pare să fi contribuit și decorul realizat de Liviu Ciulei. Ileana Popovici sintetizează atmosfera acestei puneri în scenă: „În cele mai bune momente ale spectacolului, această foarte complicată desfășurare de stări nu se organizează în simplă alăturare și succesiune, ci atinge calitatea fisiunii nucleare: una și aceeași stare (sau sentiment, sau gest) explodează sub

44. Traian Șelmaru, „Acuzarea acuzatorilor («Procesul Horia» de Alexandru Voitin la Teatrul «Lucia Sturdza Bulandra», Teatrul Național din Cluj, Teatrul Național din Craiova)“, în Teatrul, anul XII, nr. 6, iunie 1967, p. 11.

45. Ileana Popovici, „Prin teatrele din țară: Cluj - O viziune tragică a degradării: «Lungul drum al zilei către noapte» de Eugene O'Neill, regia: Crin Teodorescu“, în Teatrul, anul XIII, nr. 7, iulie 1968, p. 76. 
presiunea forțelor contrarii, descoperind terifianta ambiguitate a celor mai obișnuite și mai clare impulsuri omenești““46.

\section{Primul spectacol în București - Jocul ielelor}

Conform bazei de date Star, piesa Jocul ielelor a fost reprezentată, înainte de premiera de pe scena Teatrului Mic, doar o singură dată, la Teatrul „Sică Alexandrescu“ din Brașov (1964). Așadar, spectacolul regizat de Crin Teodorescu devine cea de-a doua punere în scenă a piesei lui Camil Petrescu. În plus, Jocul ielelor reprezintă prima montare a unui text de teatru a lui Crin Teodorescu, în calitatea sa de regizor, pe scena unui teatru din București. Cu toate că, încă de la primele sale spectacole, scenele de teatru bucureștene au intrat în contact cu spectacole semnate de Crin Teodorescu și s-au bucurat de numeroase atenții din partea criticii, primul spectacol regizat în capitală vine abia în anul 1965. Directorul de la acea dată al Teatrului Mic, Radu Penciulescu, îi propune lui Teodorescu punerea în scenă a uneia dintre piesele sale preferate, Jocul ielelor. Premiera spectacolului are loc în 2 octombrie 1965. Rezultatul se traduce în note pozitive atât din partea criticii, cât și din cea a publicului. Mirela Nedelcu subliniază, în materialul din Contemporanul, câteva dintre cele mai valoaroase câștiguri ale regiei: piesa nejucată de mai bine de cincizeci de ani a lui Camil Petrescu a beneficiat, prin punerea în scenă semnată de Crin Teodorescu, de o adaptare la timpurile actuale. Autoarea cronicii remarcă metaforele scenice folosite în compunerea spațiului de joc, precum și modalitatea cinematografică de tranziție de la o scenă la alta. Având în vedere rezultatul, un spectacol remarcabil, Mirela Nedelcu afirmă: „Crin Teodorescu își poate permite să interpreteze personal, fără să trădeze textul. Primordială la acest spectacol este evidența regândirii piesei la nivelul scenei și posibilităților moderne ${ }^{647}$. Vicu Mîndra remarcă și el, în materialul dedicat spectacolului de la Teatrul Mic, concepția și ținuta regizorală a propunerii lui Crin

46. Ibidem, p. 76.

47. Mirela Nedelcu, „«Jocul ielelor»: Premieră la Teatrul Mic“, în Contemporanul, nr. 43, 22 octombrie 1965. 
Teodorescu. Cronica sa urmează, în fapt, unui studiu destul de minuțios cu privire la tipul de abordare dramaturgică a lui Camil Petrescu și a felul de a fi al personajelor din teatrul său. Cu toate că descoperă în spectacol diferențe între cum e și cum ar fi trebuit să fie spectacolul dacă s-ar fi urmat îndeaproape piesa lui Camil Petrescu [sic!], Vicu Mîndra apreciază: „spectacolul de la Teatrul Mic restituie - în liniile sale constitutive, cu deplină responsabilitate - publicului românesc, una dintre cele mai de seamă creații ale dramaturgiei naționale“48. M. Ungheanu consideră că, odată cu spectacolul Teatrului Mic, se poate instaura tradiția montării textelor camil-petresciene, piese de teatru cărora critica de specialitate le-a remarcat în numeroase rânduri lipsa teatralității. În acest punct, plasează autorul cronicii valoarea Jocului ielelor regizat de Crin Teodorescu. M. Ungheanu remarcă faptul că această punere în scenă se bucură de un adevărat succes de public și atribuie acest lucru tocmai evitării capcanelor ce poartă etichete precum șoc sau efect regizoral. Radu Popescu nu ezită să aducă în discuție și punctele slabe ale spectacolului, așa cum a făcut-o în cronica sa și Dinu Săraru. Pentru Radu Popescu „Crin Teodorescu a lucrat prea analitic, prea minuțios, cu un exces care, în această dramă, ea însăși de excese, devine uneori frână. Acceptând un decor, operă a lui Teodor Constantinescu, cu un singur cadru general (nu lipsit de o intenție simbolică destul de facilă), el și-a răpit în mare măsură posibilitatea momentelor de atmosferă și a diminuat intensitatea frământărilor morale și psihologice, care au uneori o neașteptată rezonanță acustică, de amplificare sonoră în spațiu gol“49. Cu toate aceste minusuri, spectacolul regizat de Crin Teodorescu este considerat drept unul valoros, aflându-se între demersurile artistice cele mai de apreciat ale stagiunii 1965/1966. Dacă ar fi să i se caute spectacolului valoarea indiscutabilă, aceasta ar trebui

48. Vicu Mîndra, „Premiera unui text memorabil. «Jocul ielelor» de Camil Petrescu pe scena Teatrului Mic“, în Teatrul, anul X, nr. 11, noiembrie 1965, p. 40.

49. Radu Popescu despre spectacolul Jocul ielelor, în România liberă, 13 octombrie 1965, în: Crin Teodorescu, Maeștri ai teatrului românesc în a doua jumătate a secolului XX, ed. cit., p. 277. 
plasată, așa cum menționează și Andrei Băleanu, în „marea încărcătură de gândire, de caracter și frământare omenească, pe care o simți că o conțin replicile rostite “50.

\section{Insula pe scena Teatrului de Comedie}

La doar trei luni de la prima sa premieră pe scena unui teatru din capitală, Crin Teodorescu aduce, în fața publicului de la Teatrul de Comedie, una dintre piesele lui Mihail Sebastian, Insula. În caietul-program al spectacolului, Crin Teodorescu face următoarele observații: „această comedie, plină de gaguri și de accente bufe, e de fapt istoria unui eșec și toată mașinăria e montată ca să ne arate destrămarea unei iluzii“" ${ }^{51}$. Echipa artistică a acestui spectacol speră, prin vocea regizorului care se aude în paginile caietului-program, ca publicul să se bucure de această restituire a piesei, care se construise în spiritul autorului ei. Piesa se mai jucase doar în 1947, la București, pe scena Teatrului Municipal. Pentru spectacolul de la Teatrul de Comedie, textului neterminat al lui Sebastian i s-a adăugat un epilog, scris de Mircea Ștefănescu. Mirela Nedelcu nu ezită să menționeze pariul riscant la care s-au înhămat autorii spectacolului atunci când și-au propus să completeze, făcând apel la alte scrieri ale lui Sebastian, golurile din textul său neterminat. Cu toate aceste minusuri, autoarea cronicii consideră Insula ,un experiment interesant [...]. Impresia generală e de agreabil, fără pretenții“ ${ }^{\text {‘52 }}$. În opoziție cu perspectiva Mirelei Nedelcu, se află impresiile expuse de M. Radnev în articolul său din Informația. Acesta consideră a fi o reușită epilogul compus în stilul lui Mihail Sebastian de către

50. Andrei Băleanu despre spectacolul Jocul ielelor, în Scânteia, 22 octombrie 1965, în: Crin Teodorescu, Maeștri ai teatrului românesc în a doua jumătate a secolului XX, ed. cit., p. 279.

51. Crin Teodorescu, „Reîntâlnire cu Mihail Sebastian“, în: caietul-program al spectacolului Insula, de Mihail Sebastian, Teatrul de Comedie.

52. Mirela Nedelcu, „Retrospectiva Sebastian. «Insula» la Teatrul de comedie“, în Contemporanul, 25 februarie 1966, material accesat din arhiva Teatrului de Comedie. 
Mircea Ștefănescu, dar mai ales apreciază „operația de resta-

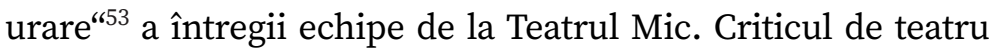
Ileana Popovici are parte, prin acest spectacol, de o surpriză neașteptată: cunoscută fiind aplecarea regizorului Crin Teodorescu înspre piesele grave, ea descoperă în Insula un spectacol mult mai plin de voie bună decât s-a așteptat, dată fiind dramaturgia lui Sebastian, dar și înclinația spre alte tonuri a regizorului. Ileana Popovici apreciază ,atmosfera antrenantă [...] actorii au fost îndrumați spre un joc structurat pe mișcare. Ei circulă aproape tot timpul prin scenă, sar, cad, se cațără, reacționează de preferință prin gesturi, instaurând un fel de «gălăgie vizuală»"54. Rezultatul, așa cum remarcă autoarea articolului, se traduce printr-o poezie scenică în care nuanțele principale sunt cele ale umanismului.

\section{Lovitura, de Sergiu Fărcășan, la Teatrul Constantin I. Nottara}

Prin spectacolul de la Teatrul Nottara, Crin Teodorescu revine la un text al dramaturgului Sergiu Fărcășan. Piesa acestuia, Lovitura, a beneficiat în aceeași stagiune de alte două puneri în scenă: una la Târgu Mureș, în regia lui George Teodorescu, și o a doua montare la Galați în regia Ancăi Ovanez, pe atunci studentă. Conform aprecierilor Anei Maria Narti, dintre aceste trei abordări, cea mai izbutită ar fi fost punerea în scenă de la Teatrul Nottara. În caietul-program al spectacolului, Crin Teodorescu menționează greutățile pe care le așază în fața regizorului textul lui Fărcășan, subliniind tocmai aceasta drept motorul care l-a atras înspre punerea în scenă a piesei. Ca de fiecare dată, Crin Teodorescu este și în acest caz atent la vibrațiile lumii contemporane și încearcă să le răspundă artistic; și de această dată, a ales o punte de lectură personală a Loviturii: „Ceea ce m-a atras spre punerea

53. M. Radnev, „«Insula» de Mihail Sebastian“, în Informația, 23 februarie 1966, material accesat din arhiva Teatrului de Comedie.

54. Ileana Popovici, „Un alt Mihail Sebastian? («Insula» de Mihail Sebastian la Teatrul de Comedie)“, în Teatrul, anul XI, nr. 3, martie 1966, p. 52. 
în scenă a piesei Lovitura este această comunitate de atmosferă, pe care o presimt, între dorințele publicului și atmosfera piesei. Trăim azi cu toții o silă față de cuvintele goale și umflate, un sârg și o dorință de a lucra și gândi precis, «a face treabă», o binecuvîntată furie și exasperare față de pierderea de vreme, intrigile stupide, demagogia în toate formele ei; în plus, spectatorul inteligent are silă față de obișnuitele explicații și «precauții» inutile cu care învăluim uneori piesele și spectacolele noastre; chiar când aude idei cu care este de acord, e plictisit dacă ele nu sînt menite decât să-i explice tâlcul «educativ» al unei situații pe care a înțeles-o și așa, fără vreun ambalaj de interpretări. Sete de fapte, repulsie față de ocolișuri și sirop, cuvinte dure, care să lovească unde trebuie, în nesimțire, răutate, prostie și ipocrizie. [...] E oare publicul dornic numai de «piesuțe» care să-i flateze obișnuințele și comoditatea? Sunt toate straturile publicului la fel, de același calibru? Fiind optimist și convins că dumneata, spectatorule, vei da un răspuns negativ, nădăjduiesc că spectacolul nostru va fi într-adevăr o «lovitură»"55. Emil Riman apreciază, în articolul său din Informația, ținuta „artistică și intelectuală“"56 a spectacolului. Ilina Grigorovici scoate la lumină lipsurile piesei lui Sergiu Fărcășan, în special faptul că teza acesteia nu este suficient de limpede, și îi reproșează regizorului faptul că nu a intervenit cu mijloacele sale specifice în această direcție în punerea lui în scenă ${ }^{57}$. În cronica amplă dedicată atât piesei lui Fărcășan, cât și celor trei puneri în scenă cu acest text, Ana Maria Narti consideră că valoarea primă a spectacolului regizat de Crin Teodorescu trebuie depozitată în dreptul construcției actoricești excelente reușite de actorul Dorin Varga, atent ghidat de cel care a semnat direcția de scenă: „principala reușită a spectacolului constă în crearea eroului principal, performanță în același timp de

55. Crin Teodorescu, „Despre Lovitura“, în caietul-program al spectacolului Lovitura, de Sergiu Fărcășan, Teatrul Nottara.

56. Emil Riman, „Teatrul C.I. Nottara «Lovitura» de Sergiu Fărcășan“, în Informația, 23 octombrie 1977.

57. V. Ilina Grigorovici, „«Lovitura» de Sergiu Fărcășan la Teatrul «C. I. Nottara»", în Scânteia tineretului, 8 noiembrie 1967. 
interpretare și regizorală, pentru că Dorin Varga este în mare măsură un actor format de Crin Teodorescu“58.

\section{Victimele datoriei la Teatrul Bulandra ${ }^{59}$}

În caietul-program al spectacolului, Crin Teodorescu nu își mai schițează argumentele care au stat la baza lecturii regizorale a textului ionescian. Selectează însă fragmente din scrieri ale lui Eugen Ionescu și îl lasă, astfel, pe acesta să vorbească despre teatru. În schimb, regizorul aduce în discuție tipul spectatorului deschis în fața propunerilor artistice, a spectatorului care, atunci când vine într-o sală de spectacol, dincolo de logic, caută, explorează voci sau tonuri ale adevărului, potrivite de autorii spectacolului nu prin abordări teziste, ci prin construcția scenică a firelor care compun un astfel de adevăr: „unor asemenea spectatori socotesc că nu e hazardat să le propunem seducțiile unui teatru oniric, cum e spectacolul pe care-l veți vedea astă seară - teatru care își desfășoară noile sale ceremoniale și magii pe fondul de violență și agresiune al lumii moderne ${ }^{\text {660 }}$. Din lectura cronicilor care vorbesc despre Victimele datoriei, reiese reușita demersului regizoral, fiecare dintre aceste înregistrări ale spectacolului menționând angrenajul artistic excepțional rezultat. Andrei Strihan apreciază propunerea Teatrului Bulandra drept „un spectacol ionescian de autentică originalitate“61, elogiind în mod deosebit libertatea creativă pusă la dispoziția actorilor de către regizorul spectacolului: ,pentru a da actorilor o deplină libertate de mișcare corporală, pentru ca demonstrația acestora să se bazeze numai pe resursele lor interioare,

58. Ana Maria Narti, „De trei ori «Lovitura»“, în Teatrul, anul XIII, nr. 2, februarie 1968, p. 55.

59. V., în acest sens, și materialul semnat de Mirella Patureau disponibil pe platforma Dicționarul Multimedia al Teatrului Românesc, la adresa: https://www.dmtr.ro/spectacol/victimele-datoriei/.

60. Crin Teodorescu, „Pseudocuvânt al regizorului“, în caietul-program al spectacolului Victimele datoriei, de Eugen Ionescu, material disponibil în arhiva Teatrului Bulandra.

61. Andrei Strihan despre spectacolul Victimele datoriei, în 
pentru ca irealul să fie rezultatul unui astfel de efort artistic, regizorul renunță la artificii: vârsta fiind, de exemplu, marcată nu prin machiaj, perucă, mască sau costumație, ci prin joc"62. Într-un astfel de cadru, la care se adaugă și spațiul excepțional gândit de Paul Bortnovschi (senzația generată de albul spațiului scenic este amintită în fiecare dintre aceste cronici), s-a construit un spectacol de un înalt profesionalism, așa cum remarcă și Sanda Faur, în articolul ei publicat în Flacăra. Ana Maria Narti menționează filonul umanist pe care Crin Teodorescu a reușit să-1 scoate la suprafața lumii ionesciene, evidențiind faptul că actorii implicați în generarea acestui spectacol s-au văzut nevoiți să-și construiască o nouă gramatică de expresie scenică: echipa de actori a proiectului a fost nevoită să-și pună în joc atât resursele fizice, cât și pe cele intelectuale, „să joace, în locul caracterelor, stări fragmentare, sentimente-senzații; să potențeze idei-situații, să părăsească explicitarea simplistă, descoperind legătura subterană a înlănțuirilor metaforice “63.

\section{Prețul, de Arthur Miller, pe scena Teatrului Mic din București}

Ultimul spectacol realizat de Crin Teodorescu pe scena Teatrului Mic aduce în prim-plan dramaturgia americană, dramaturgie asupra căreia regizorul mai poposise și în punerile sale în scenă anterioare. De data aceasta, a ales Prețul, piesa lui Arthur Miller. În materialele dedicate spectacolului, atât Mira Iosif, cât și S. Costin remarcă elemente recurente, caracteristice direcției de scenă semnate de Crin Teodorescu: respectul față de opera dramaturgică de la care, de fiecare dată, pornește construcția spectacolului, fidelitatea față de temele și direcțiile autorului, precum și

Contemporanul, nr. 1, 3 ianuarie 1969, în: Crin Teodorescu, Maeștri ai teatrului românesc în a doua jumătate a secolului XX, ed. cit., p. 289. 62. Ibidem.

63. Mira Iosif, „«Victimele datoriei» de Eugen Ionescu la teatrul «Lucia Sturdza Bulandra»", în Teatrul, anul XIV, nr. 2, februarie 1969, p. 54. 
așezarea actorului în centrul demersului teatral. Andrei Strihan scoate și el la lumină coordonate esențiale ale gândirii regizorale, argumentând: „Sub îndrumarea lui Crin Teodorescu, regizor care îmbină armonios facultatea teoretică cu capacitatea de a intui și de a valorifica la maximum talentul interpreților, patru actori ai Teatrului Mic - Ion Marinescu, Doina Tuțescu, Gh. Ionescu-Gion și Tudorel Popa - ne invită, în reprezentația Prețului de Arthur Miller, la o pasionantă dezbatere de idei și la un esențial proces psihologic din lumea contemporană“64. Mira Iosif, în articolul „«Prețul» sau parabola responsabilității“, remarcă funcționarea ansamblului scenic asemenea unei orchestre conduse impecabil. În ceea ce privește jocul actorilor, ea menționează evitarea teatralismului și deplasarea atenției acestuia înspre tensiune interioară.

\section{Harfa de iarbă, de Truman Capote (Teatrul Bulandra). Ultimul spectacol.}

Demersul artistic pe care și 1-a propus cu acest spectacol trebuie plasat, așa cum însuși regizorul mărturisește în articolul său din România literară, la polul opus celui gândit pentru spectacolul Victimele datoriei: „Este absolut necesar ca fiecare actor să aducă cu el în scenă un univers care să capete prezență dincolo de replicile dialogului. Pentru că întocmai imaginii cu care-și caracteriza Hemingway stilul acel iceberg care abia se vede la suprafața apei, păstrându-și masa ascunsă în ocean - ceea ce spun explicit persoanele lui Capote epuizează doar o mică parte din realitățile psihologice, sociale sau chiar metafizice pe care ele le implică“65. Conform observațiilor pe care le face Mira Iosif în articolul din revista Teatrul $^{66}$, pariul regizorului în ceea ce privește

64. Adrian Strihan despre spectacolul Prețul, în Contemporanul, 1969 în: Crin Teodorescu, Maeștri ai teatrului românesc în a doua jumătate a secolului XX, ed. cit., p. 295.

65. Crin Teodorescu, „Truman Capote pe scenă“, în România literară, nr. 4, 1970, p. 25.

66. V. Mira Iosif, „Cronica dramatică: «Harfa de iarbă» de Truman Capote 
trupa de actori a fost unul câștigat; în schimb, autoarea cronicii menționează dezorientarea regizorului atunci vine vorba de citirea piesei lui Truman Capote, acesta neizbutind, de această dată, să se plieze peste spiritul scriiturii autorului. Aceeași impresie este împărtășită și de George Banu. Acesta susține că spectacolului îi lipsește atmosfera. În plus, „inexplicabil pentru Crin Teodorescu, spectacolul deranjează și prin neglijență. În primul rând rezolvările, în manieră revuistică, pentru a descrie lumea orașului, lipsesc piesa de unul din termenii ei, iar, apoi, de cele mai multe ori ele sînt ininteligibile“67. Florica Ichim subliniază, în aprecierile sale ${ }^{68} \mathrm{cu}$ privire la acest spectacol, faptul că translatarea pe care și-a dorit-o Capote atunci când a decis să-și dramatizeze o nuvelă, nu a reușit; acesta este poate unul dintre minusurile care se răsfrânge inevitabil și asupra punerii în scenă. Însă autoarea cronicii menționează că, în versiunea de spectacol de la Teatrul Bulandra, actorii sunt cei care aduc în scenă acea poezie a poveștii pe care însuși Capote o pierduse în procesul de adaptare pentru scenă a propriei bucăți de literatură. Clody Bertola, cea care în Harfa de iarbă a interpretat-o pe Dolly Talbo, rememorează, într-un articol apărut în România literară în ziua de 6 aprilie 1970, câteva dintre lucrurile care au impresionat-o în lucrul cu Crin Teodorescu la acest spectacol: „Piesa lui Truman Capote - de fapt, o schiță dramatizată - ne-a opus de la început câteva dificultăți, în ciuda simplității ei aparente. Primejdiile melodramei, ale edulcorației, ale idilismului ne pîndeau la fiecare pas ca niște aligatori ascunși în undele unei ape liniștite și aparent inofensive. În plus, cum toate rolurile aveau o greutate aproape egală, regizorul trebuia să demonstreze o adevărată virtuozitate în distribuirea acelei ponderi specifice fiecărui personaj de care era nevoie pentru realizarea unui spectacol bun. [...] În timpul repetițiilor, Crin Teodorescu teoretiza mult și era interesant

(Teatrul «Lucia Sturdza Bulandra»)", în Teatrul, anul XV, nr. 4, aprilie 1970. 67. George Banu, „O distribuție strălucită și totuși...., în România literară, nr. 14, 1970.

68. V. Florica Ichim, „«Harfa de iarbă» de Truman Capote“, în Munca, 25 martie 1970. 
pentru noi să-1 urmărim. Teoretizarea lui nu numai că nu încărca repetițiile și nu le rupea fluxul, ci dimpotrivă ne ajuta de foarte multe ori să găsim apoi corespondența principiilor emise de regizor, evident, atunci cînd erau acceptate de noi pe plan practic. Am schițat, doar, imaginea pe care o păstrez despre Crin Teodorescu. Știrea morții lui m-a tulburat cumplit, e prea recentă și nu-mi pot aduna încă toate gîndurile și toate amintirile despre el“69.

Crin Teodorescu se pregătea să monteze Revizorul.

\section{Bibliografie:}

\section{Cărți:}

*** Crin Teodorescu. Maeștri ai teatrului românesc în a doua jumătate a secolului XX, coordonator Valeriu Moisescu, București, UNATC, 2001.

*** Teatrul românesc contemporan 194-1974, coordonatorii ediției: Simion Alterescu, Ion Zamfirescu, București, Meridiane, 1975.

MoIsescu, Valeriu, Persistența memoriei, București, Fundația Culturală „Camil Petrescu“, Revista Teatrul azi (supliment), 2007.

Morariu, Mircea, Carte cu Gina Patrichi, București, Fundația Culturală „Camil Petrescu“, Revista Teatrul azi (supliment), 2009.

OPREA, Ștefan, Martor al Thaliei, Iași, Editura Junimea, 1979.

Runcan, Miruna, Teatru in diorame. Discursul criticii teatrale în comunism. Fluctuantul dezgheț 1956-1964, București, Tracus Arte, 2019.

\section{Articole semnate de Crin Teodorescu:}

TEOdorescu, Crin, „Viitorul aparține unor colective mici“, în Teatrul, anul XII, nr. 12, decembrie 1967.

TEODORESCU, Crin, „Truman Capote pe scenă“, în România literară, nr. 4, 1970.

69. Clody Bertola, „Câteva gânduri despre Crin Teodorescu“, în România literară, 6 aprilie 1970, p. 25. 


\section{Cronici de spectacol:}

BANU, George, „O distribuție strălucită și totuși...., în România literară, nr. 14, 1970.

BERTOLA, Clody, „Câteva gânduri despre Crin Teodorescu“, în România literară, 6 aprilie 1970.

CRIVĂȚ, Dana, „Prin teatrele din țară: Iași“, în Teatrul, anul X, nr. 6, iunie 1965.

CRIVĂȚ, Dana, „Prin teatrele din țară: Iași - «Îmbrăcați pe cei goi» de Luigi Pirandello, «Întîlnire la Copenhaga» de Yves Jamiaque“, în Teatrul, anul XIII, nr. 4, aprilie 1968.

DRîMBA, Ovidiu, „Mai multă plastic decît idei“, în Teatrul, anul II, nr. 9, septembrie 1957.

GRIGOROVICI, Ilina, „«Lovitura» de Sergiu Fărcășan la Teatrul «C. I. Nottara»", în Scânteia tineretului, 8 noiembrie 1967.

ICHIM, Florica, „«Harfa de iarbă» de Truman Capote“, în Munca, 25 martie 1970.

IosıF, Mira, „În zilele Decadei“, în Teatrul, anul I, nr. 3, august 1956. IosIF, Mira, „«Victimile datoriei» de Eugen Ionescu la teatrul «Lucia Sturdza Bulandra»“, în Teatrul, anul XIV, nr. 2, februarie 1969.

Iosıf, Mira, „Cronica dramatică: «Harfa de iarbă» de Truman Capote (Teatrul «Lucia Sturdza Bulandra»)“, în Teatrul, anul XV, nr. 4, aprilie 1970.

MînDRA, Vicu, „Premiera unui text memorabil. «Jocul ielelor» de Camil Petrescu pe scena Teatrului Mic“, în Teatrul, anul X, nr. 11, noiembrie 1965.

NARTI, Ana Maria, „Procesul Horia văzut de regizorii Liviu Ciulei și Crin Teodorescu“, în Teatrul, anul XII, nr. 3, martie 1967.

NARTI, Ana Maria, „De trei ori «Lovitura»“, în Teatrul, anul XIII, nr. 2, februarie 1968.

NEDELCU, Mirela, „«Jocul ielelor»: Premieră la Teatrul Mic“, în Contemporanul, nr. 43, 22 octombrie 1965.

Nedelcu, Mirela, „Retrospectiva Sebastian. «Insula» la Teatrul de comedie“, în Contemporanul, 25 februarie 1966, material accesat din arhiva Teatrului de Comedie.

NiCOLAU, Florin, „«Bălcescu» de Camil Petrescu la Teatrul Național «Vasile Alecsandri»", în Teatrul, anul IX, nr. 12, decembrie 1964. PARAschivescu, C., „Teatrul National din lași: «Despot Vodă» de Vasile Alecsandri“, în Teatrul, anul XII, nr. 2, februarie 1967. 
PopovicI, Ileana, „Spectacole Shakespeare“, în Teatrul, anul IX, nr. 9, septembrie 1964.

PoPovicI, Ileana, „Prin teatrele din țară: Cluj - O viziune tragică a degradării: «Lungul drum al zilei către noapte» de Eugene O’Neill, regia: Crin Teodorescu, în Teatrul, anul XIII, nr. 7, iulie 1968.

PopovicI, Ileana „Un alt Mihail Sebastian? («Insula» de Mihail Sebastian la Teatrul de Comedie)“, în Teatrul, anul XI, nr. 3, martie 1966.

POTRA, Florian, „Două spectacole de tragedie ateniană“, în Teatrul, anul IX, nr. 5, mai 1964.

RADNEV, M., „«Insula» de Mihail Sebastian“, în Informația, 23 februarie 1966.

RAFAEL, George, „Un preludiu promițător“, în Teatrul, anul I, nr. 3, august 1956.

RIMAN, Emil, „Teatrul C.I. Nottara «Lovitura» de Sergiu Fărcășan“, în Informația, 23 octombrie 1977.

ŞELMARU, Traian, „Acuzarea acuzatorilor («Procesul Horia» de Alexandru Voitin la Teatrul «Lucia Sturdza Bulandra», Teatrul Național din Cluj, Teatrul Național din Craiova)“, în Teatrul, anul XII, nr. 6, iunie 1967.

TORNEA, Florin, „Crin Teodorescu și căile tragicului modern: «Din jale se întrupează Electra» de Eugene O'Neill la Teatrul Național «Vasile Alecsandri» din Iași“, în Teatrul, anul XI, nr. 11, noiembrie 1966.

\section{Interviuri:}

„PASIUNE și însuflețire în arta teatrală, convorbire cu artistul poporului Costache Antoniu despre decada dramaturgiei originale“, în: Scânteia, anul XXV, nr. 3616, vineri 8 iunie 1956.

\section{Caiete-program:}

„DE VORBĂ cu Crin Teodorescu regizorul spectacolului“, material disponibil în caietul-program al spectacolului Vară și fum, Teatrul Național „Vasile Alecsandri“ Iași.

TEOdoRESCU, Crin, „Opinii regizorale“, extras din caietul-program al spectacolului Steaua polară, de Sergiu Fărcășan, Teatrul Național „Vasile Alecsandri“ Iași.

TEODORESCU, Crin, „Cuvântul regizorului“, extras din caietul-program al spectacolului Bălcescu, Teatrul Național „Vasile Alecsandri“ Iași. 
TEOdoREscu, Crin, „Reîntâlnire cu Mihail Sebastian“, extras din caietul-program al spectacolului Insula, de Mihail Sebastian, Teatrul de Comedie.

TEODORESCU, Crin, „Despre Lovitura“, în caietul-program al spectacolului Lovitura, de Sergiu Fărcășan, Teatrul Nottara.

TEOdorescu, Crin, „Pseudocuvânt al regizorului“, în caietul-program al spectacolului Victimele datoriei, de Eugen Ionescu. 